\title{
Characterisation of Municipal Solid Waste Compost (MSWC) from Selected Indian Cities-A Case Study for Its Sustainable Utilisation
}

\author{
Manju Rawat*, AL. Ramanathan, T. Kuriakose \\ School of Environmental Sciences, Jawaharlal Nehru University, New Delhi, India. \\ Email: *mrawat@yahoo.com
}

Received December $3^{\text {rd }}, 2012$; revised December $31^{\text {st }}, 2012$; accepted January $22^{\text {nd }}, 2013$

\begin{abstract}
Utilisation of Municipal Solid Waste is important to curb the ever rising demand of scarce land for its disposal. Changing life style patterns, particularly in urban areas, has led to increase in generation of MSW. Municipal solid waste from Indian cities estimated to have $40 \%-60 \%$ organic matter, which could be recycled as compost. The most suitable way to recycle it with low investment is aerobic composting using windrow method. With the compliance of Municipal Solid Waste (Management and Handling) Rules 2000, many cities in India are making compost with organic portion of MSW. Before applying MSWC for agricultural uses, it is important to inventories heavy metals in compost to assess its toxicity. In the present study the compost samples were quantified for its toxicity from three highly populated cities of India, i.e., Delhi (Capital of India), Ahmedabad (Gujarat) and Bangalore (Karnataka). The MSWC samples were analysed for total heavy metals and in extractable fractions. Few samples were found with higher concentration of metals then the prescribed limits for its application as compost in Indian MSW rules, whereas, samples have not showed significant heavy metals concentration in extractable fractions. Therefore, studied MSW compost samples had demonstrated its suitability to use as green compost.
\end{abstract}

Keywords: Municipal Solid Waste; Compost; Indian Cities; Fractionation; Heavy Metals

\section{Introduction}

In India, composting of bio-degradable municipal solid wastes has been made mandatory by the Supreme Court (SC) following the recommendations made by the Burman Committee report in 1999. Subsequently, the $\mathrm{Mu}-$ nicipal Solid Waste (Management and Handling) Rules 2000, also encourage this [1,2]. In May 2007, the Supreme Court of India laid down that compost and biomethanation technologies were appropriate in view of the quality of MSW generated. Such as MSW had high organic waste $(40 \%-60 \%)$, high moisture contents and therefore low calorific values around $800-1200 \mathrm{kcal} / \mathrm{kg}$ [3]. Indian Government is also encouraging MSW management by the Jawaharlal Nehru National Urban Rural Mission (JNNURM) scheme, where a part of budget could be shared by state government for running waste processing plant in states and districts. On the other way as organic components is high in MSW from Indian cities, thus it is not suitable for waste to energy generation or for refuse derived fuel (RDF), incineration, pyrolysis etc.

${ }^{*}$ Corresponding author.
The Municipal Solid Waste (MSW) generation has increased in India from $100 \mathrm{~g} /$ day/person to $450 \mathrm{~g} /$ day/ person after Independence (1947). The total MSW generation in India is around 48 million tons per annum and this would increase to 300 million tons by the year 2047 (Table 1). Municipal solid waste in Indian mega-cities is mainly disposed in landfills by means of open dumping however; a small fraction from that is used for composting in Delhi (National Capital Territory of India) and Mumbai, while in Chennai and Kolkata composting facility is being implemented and is presently, in pilot stage [4]. In other cities like Bangalore and Ahmedabad is being taken up on an experimental basis by either Non-Government Organisation (NGO's) or Private Companies. Jha et al. [4], had also tabulated data of physical characterisation of meteropolitan cities of India for two decades (1971-2002) and that shows that there is not much difference in physical characteristics though MSW generation has increased to great extent.

Domestic and commercial wastes are commonly termed as MSW and both these account for bulk of the waste in developing countries [6]. For beneficial management, wastes should be regarded as "a resource in the 
Table 1. MSW generation for 100 years in India.

\begin{tabular}{cccc}
\hline Years & 1947 & 1997 & 2047 \\
\hline $\begin{array}{c}\text { Urban population } \\
\text { (millions) }\end{array}$ & 56.9 & 247 & - \\
$\begin{array}{c}\text { Daily per capita waste } \\
\text { generation (grams) }\end{array}$ & 295 & 490 & 927 \\
$\begin{array}{c}\text { Total waste generated } \\
\text { (million tones) }\end{array}$ \\
$\begin{array}{c}\text { Area under land fills } \\
\text { (thousand of hectares) }^{* *}\end{array}$ & 0.12 & 20.2 & 300 \\
$\begin{array}{c}\text { Annual methane emissions } \\
\text { (million tones) }^{* *}\end{array}$ & 0.87 & 7.1 & 39 \\
\hline
\end{tabular}

Source: ${ }^{*}$ Census of India 2001, ${ }^{* *}$ Singla and Pandey [5].

wrong place", as botanist regards weed as "a plant in the wrong place", waste generally refers useless remains with lack of value. A basic way to deal with waste is to restore value from it. But in most of the developing countries, in major cities MSW is made to compost. Generally, manual segregation has been done for MSW, but if segregation is not done properly, there is possibility of heavy metals to enter in our food chain. Therefore, need arises to inventories the metal in MSW.

Composting is a simplest way to restore value in MSW. Aerobic composting with windrows method after proper segregation of MSW is recognized as a cost-effective method that results in an end product that can be used as soil amendment. Several authors $[7,8]$ have reported beneficial effects of compost on soil productivity. These developments can be examined from the perspectives of waste management, agriculture and climate change. The technology to be used for this purpose is relatively simple and affordable, while the end-product is beneficial for soil and ensures significant saving of scarce land (required for land-filling). However, public-private partnership efforts are constrained due to quality requirements, marketing, pricing issues and ways to make it sustainable on a long-term basis [9]. The reducing, reusing, recycling and rebuying - the 4 R's is key of diverting organic materials from landfill and prevents greenhouse gases (GHG's) emissions, reduces pollutants, conserves resources and reduces the need for new disposal facilities [10].

In this paper, chemical characterization for macronutrients $(\mathrm{C}, \mathrm{N}$ and $\mathrm{P})$ and heavy metals $(\mathrm{Cu}, \mathrm{Cr}, \mathrm{Ni}, \mathrm{Pb}$ and Cd) of MSW compost had been done for three Indian mega cities i.e., Ahmedabad (Gujarat), Bangalore (Karnataka) and Delhi (Capital of India) to assess its quality for applying as soil conditioner and fertilisers. There are limited works reported in India on the impact of MSWC on vegetative crops. Begum [11], reported application of MSWC of Bangalore city on tomato plant that on application of MSW compost around $192 \mathrm{~g} /$ pot, the $\mathrm{Zn}, \mathrm{Cu}$,
$\mathrm{Ni}$ and $\mathrm{Pb}$ contents of tomato plant were found in high levels. Many other authors have reported metals uptake by the application of Industrial solid waste on plant in India [12].

The population of the studied cities is, Ahmedabad 5.8 millions, Bangalore 6.5 millions and Delhi 13.8 million (Census 2001). The physical characterisation of MSW in metropolitan's cities of India is given in Table 2. Around $100-300$ tones of segregated MSW per day are collected to make compost in Delhi, Bangalore and Ahmedabad. In Delhi and Ahmedabad MSW is collected by municipal authorities and given to private companies to make compost. In Bangalore, Karnataka Compost Development Corporation (KCDC) Limited is collecting MSW and making compost. The compost collected for present study is being made by aerobic composting by windrows methods with mechanically or manual segregation. A regular monitoring of quantification of heavy metals should be necessary as excessive application of compost may lead to the accumulation of heavy metals in soil surface $[13,14]$. Not only are these heavy metals non-biodegradable and become toxic at some levels, but also they tend to accumulate along the food chain, where human is the last link $[15,16]$. Beside that, for heavy metals distribution and transportation to soil and ground water was studied by sequential extraction $[17,18]$. In this paper, regulatory compliance has given more focused then agricultural productivity to study the quality of compost.

\section{Material and Methods}

\subsection{Sample Collection and Processing}

The ten representative samples of municipal solid waste compost was collected from three metropolitans cities of India, i.e., from Pirana landfill compost, Ahmedabad; KCDC sites, Bangalore; Okhla MSWC, Delhi. These samples were collected by stainless steel auger in airtight polythene bags after proper mixing and then labeled carefully. The samples were carried to laboratory and stored in a cold room at a temperature of $4^{\circ} \mathrm{C}$ for further analysis. Samples were dried at room temperature, homogenised and sub-sampled by quartering and ground to pass through $2 \mathrm{~mm}$ sieve. These processed samples were sub sampled for further analysis.

\subsection{Methodology Used for Analysis of Samples}

The $\mathrm{pH}$ and Electrical Conductivity (EC) of samples were measured immediately after bringing them to the laboratory, using 1:10 ratio of $w / v$ with deionised distilled water by $\mathrm{pH}$ meter and EC meter respectively. Other parameters Moisture Contents (MC), Kjeldhal's Nitrogen and Phosphorus (by Olsen and Bray method) in samples were measured according to methodology given 
Table 2. Physical characteristics of MSW in Indian metrocities.

\begin{tabular}{|c|c|c|c|c|c|c|c|c|}
\hline \multicolumn{9}{|c|}{ Characteristics ( $\%$ by weight) } \\
\hline Name of metrocity & Paper & Textile & Leather & Plastic & Metals & Glass & Ash, fine earth and others & Compostable matter \\
\hline Ahmedabad & 6.0 & 1.0 & - & 3.0 & - & - & 50.0 & 40.00 \\
\hline Bangalore & 8.0 & 5.0 & - & 6.0 & 3.0 & 6.0 & 27.0 & 45.00 \\
\hline Bhopal & 10.0 & 5.0 & 2.0 & 2.0 & - & 1.0 & 35.0 & 45.00 \\
\hline Mumbai* $^{*}$ & 15 & 3.14 & - & - & 0.80 & 0.40 & 35.0 & 37.5 \\
\hline Kolkata $^{*}$ & - & - & - & 1.54 & 0.66 & 0.24 & 35.0 & 46.58 \\
\hline Delhi $^{*}$ & 3.62 & 0.52 & 0.85 & 4.17 & 0.45 & 0.49 & 36.56 & - \\
\hline Hyderabad & 7.0 & 1.7 & - & 1.3 & - & - & 50.0 & 40.00 \\
\hline Kanpur & 5.0 & 1.0 & 5.0 & 1.5 & - & - & 52.5 & 40.00 \\
\hline Kochi & 4.9 & - & - & 1.1 & - & - & 36.0 & 58.00 \\
\hline Lucknow & 4.0 & 2.0 & - & 4.0 & 1.0 & - & 49.0 & 40.00 \\
\hline Chennai* $^{*}$ & 6.45 & - & 1.45 & 7.04 & 0.03 & - & 34.65 & 47.24 \\
\hline Madurai & 5.0 & 1.0 & - & 3.0 & - & - & 46.0 & 45.00 \\
\hline Patna & 4.0 & 5.0 & 2.0 & 6.0 & 1.0 & 2.0 & 35.0 & 45.00 \\
\hline Surat & 4.0 & 5.0 & - & 3.0 & - & 3.0 & 45.0 & 40.00 \\
\hline
\end{tabular}

Source: Central Pollution Control Board [3], Jha et al. [4]*.

in Okalebo et al. [19]. Samples were analysed for the total and Inorganic carbon and sulphur (against suitable salt standard) using the LS-1000, Eltra, auto CS analyser.The organic carbon and sulphur contents were computed as the difference between the total and inorganic fractions.

For bulk analysis of heavy metals, $0.1 \mathrm{~g}$ of finely grounded solid waste samples and soil samples were digested with triple acid using standard method given by Loring and Rantala [20], and analysed by Atomic Absorption Spectrophotometer (AAS), Shimadzu AA 1600. The Canadian soil standards $\mathrm{SO}_{1}, \mathrm{SO}_{2}, \mathrm{SO}_{3}$ and $\mathrm{SO}_{4}$ were digested in same manner and used for calibration. Precision and atomic absorption analysis on replicated samples was estimated against standards. A deviation of $\pm 5 \%$ - $10 \%$ was observed for heavy metals values of standards from their certified values. The detection limits of instrument for heavy metals were as $\mathrm{Fe} 0.05$, Mn 0.02, $\mathrm{Zn} \mathrm{0.01,} \mathrm{Cu} \mathrm{0.03,} \mathrm{Cd} \mathrm{0.01,} \mathrm{Cr} \mathrm{0.05,} \mathrm{Pb} 0.02$ and Ni 0.04 $\mathrm{mg} / \mathrm{kg}$. All chemicals used for this analysis were from MERCK of high purity. Stock solutions were prepared by using ultra pure deionizer MilliQ water.

Sequential extraction of heavy metals was carried out according to the procedure of $\mathrm{Ma}$ and Rao [18], and Tessier et al. [21], with five representative samples, which is widely applied in various studies done on compost $[16,22-24]$. Six operationally defined chemical frac- tions separated, viz. water-soluble, exchangeable, carbonate-bound, Fe-Mn oxides, organic-bound and residual fractions. Each of the chemical fractions of $\mathrm{Cu}, \mathrm{Cr}, \mathrm{Ni}$, $\mathrm{Pb}$ and $\mathrm{Cd}$ in the MSWC is operationally fractionated in six fractions as Water soluble fraction (F1), Exchangeable fraction of metals (F2), Carbonate bound fraction (F3), Metals from reducible iron and manganese bound fraction (F4), Organic fraction bound metals (F5), Residual fraction of metals (F6) and blanks were also run at the same time to take care of all precision during analysis [25].

\section{Result and Discussion}

All the result gathered from analyses of samples collected from the study areas were given in Tables $\mathbf{3}$ and $\mathbf{4}$ and in Figure 1.

\section{1. pH and Electrical Conductivity (EC), Organic Matter (OM) and Moisture Contents (MC)}

The average value of $\mathrm{pH}$ for Ahmedabad city was 8.06 , for Bangalore as 8.19 and for Delhi as 7.82. The $\mathrm{pH}$ value was observed for compost samples as slightly alkaline in nature and was well within the standard limits of 5.5 - 8.5 (Table 4). Mkhabeta and Warman [26], had stated that the major advantage of application of MSWC 
Table 3. Physio-chemical properties of municipal solid waste compost.

\begin{tabular}{ccccccccc}
\hline & $\begin{array}{c}\text { Total MSW from } \\
\text { city (tons/day) }\end{array}$ & $\begin{array}{c}\text { Population } \\
\text { (million) }^{*}\end{array}$ & OM (\%) & MC (\%) & C (\%) & N (\%) & P (\%) & C/N \\
\hline Ahmadabad & 1200 & 5.8 & $42.16( \pm 2.64)$ & $29.32( \pm 5.00)$ & $21.56( \pm 4.04)$ & $0.85( \pm 0.27)$ & $2.82( \pm 0.37)$ & 25.36 \\
Bangalore & 2200 & 6.5 & $46.78( \pm 9.20)$ & $31.61( \pm 7.02)$ & $26.61( \pm 5.18)$ & $1.13( \pm 0.46)$ & $2.92( \pm 0.34)$ & 23.55 \\
Delhi & 6500 & 13.8 & $37.52( \pm 3.28)$ & $23.83( \pm 5.07)$ & $19.56( \pm 6.68)$ & $1.03( \pm 0.46)$ & $2.52( \pm 0.29)$ & 18.99 \\
\hline
\end{tabular}

OM—Organic Matter, MC—Moisture Contents, C—Total Carbon, N-Kjeldhal's Nitrogen, P—total Phosphorus, C/N—Carbon/ Nitrogen ratio. ${ }^{*}$ Indian Census 2001 .

Table 4. Average concentration (mg/kg) of heavy metals in municipal solid waste compost (MSWC).

\begin{tabular}{cccccccc}
\hline & $\mathbf{p H}$ & $\mathbf{E C}(\mathbf{m S} / \mathbf{c m})$ & $\mathbf{C u}$ & $\mathbf{C r}$ & $\mathbf{N i}$ & $\mathbf{P b}$ & $\mathbf{C d}$ \\
\hline $\begin{array}{c}\text { Indian standards for } \\
\text { compost from MSW }\end{array}$ & $5.5-8.5$ & - & 300 & 50 & 50 & 100 & 5 \\
Ahmadabad & $8.06( \pm 0.37)$ & $0.71( \pm 0.07)$ & $36.68( \pm 9.32)$ & $21.14( \pm 9.87)$ & $26.04( \pm 8.20)$ & $8.18( \pm 1.91)$ & $3.69( \pm 1.34)$ \\
Bangalore & $8.19( \pm 0.29)$ & $0.58( \pm 0.11)$ & $34.43( \pm 7.5)$ & $7.28( \pm 1.56)$ & $2.18( \pm 0.80)$ & $6.58( \pm 1.64)$ & $2.32( \pm 1.62)$ \\
Delhi & $7.82( \pm 0.42)$ & $0.83( \pm 0.078)$ & $48.47( \pm 7.92)$ & $36.42( \pm 10.74)$ & $34.52( \pm 2.56)$ & $21.76( \pm 4.32)$ & $2.61( \pm 1.65)$ \\
\hline
\end{tabular}

EC-Electrical Conductivity.
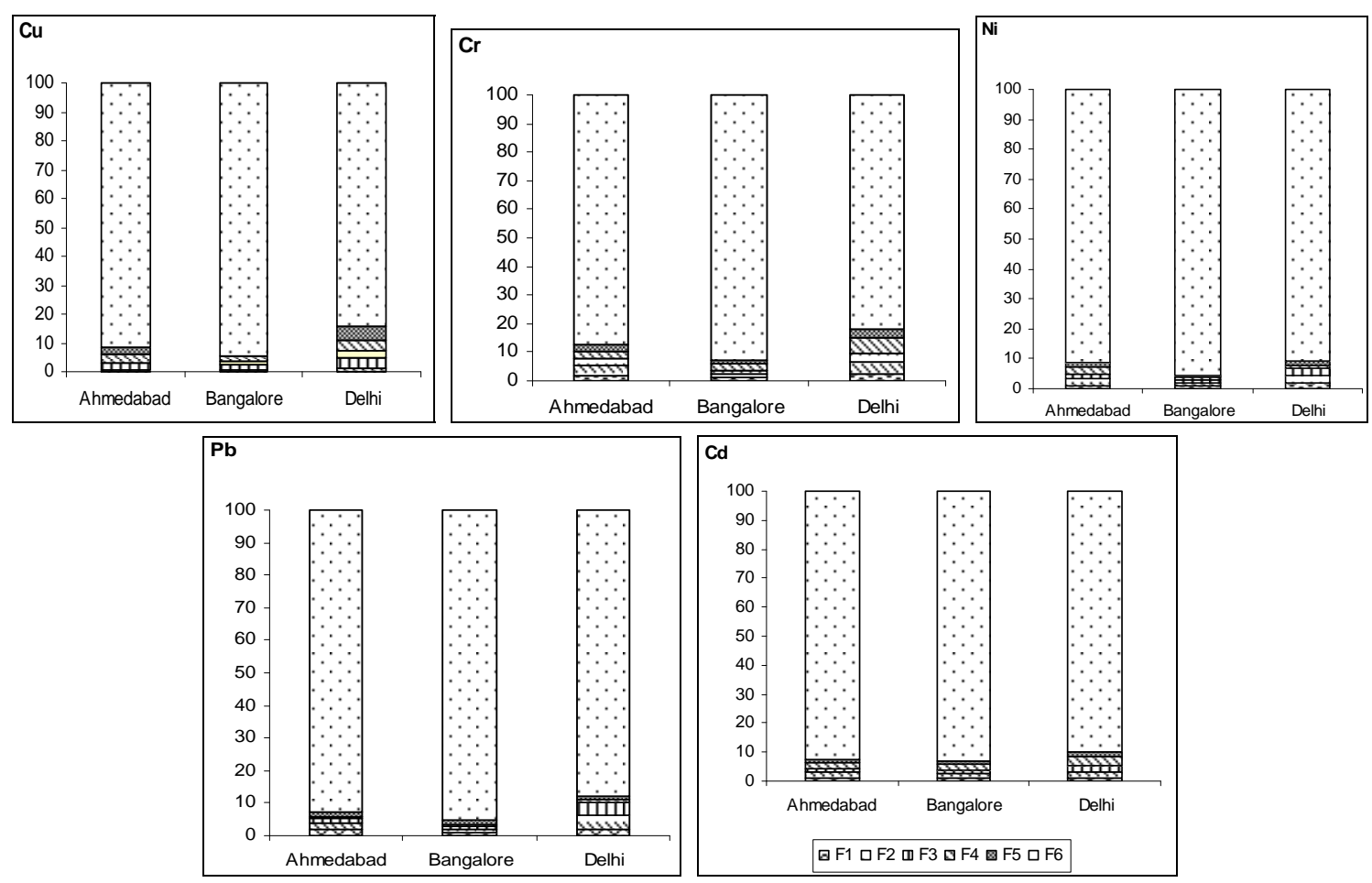

Figure 1. Fractionation of heavy metals in municipal solid waste compost. (F1—water soluble, F2—exchangeable fraction, F3-carbonate fraction, F4—Fe-Mn oxide, F5—organic bound, F6-residual fraction).

is soil $\mathrm{pH}$ increase to some extend. This increase in $\mathrm{pH}$ is due to the mineralisation of $\mathrm{C}$ and subsequent production of $\mathrm{OH}^{-}$ions by ligand exchange as well as introduction of basic cations, such as $\mathrm{K}^{+}, \mathrm{Ca}^{++}$and $\mathrm{Mg}^{++}$. Brady and Weil [27], had reported that micronutrients and metalcations are most soluble and available for plant uptake un- der acidic conditions so MSWC would help in mitigating the heavy metals availability.

EC is an important parameter to determine the compost quality as high salt concentration can inhibit the seed germination [28] so it is essential to measure the EC of compost before its application as a soil conditioner. 
The samples collected from Ahmedabad showed EC value as $0.71 \mathrm{mS} / \mathrm{cm}$, Bangalore as $0.58 \mathrm{mS} / \mathrm{cm}$ and Delhi as $0.83 \mathrm{mS} / \mathrm{cm}$ (Table 4). Manios [29], analysed that pressed grape skins should be considered as the ideal raw material, producing high quality compost, with the lowest $\mathrm{EC}$ value $(1.57 \mathrm{mS} / \mathrm{cm})$. Therefore, a salt content in the MSWC was in the limits of its application to the field. Brady and Weil [27], were reported EC levels ranges from $0.369-0.749 \mathrm{mS} / \mathrm{cm}$ in MSWC. However, some studies had showed that high EC values in MSWC inhabit the plant growth [28]. In the present study the $\mathrm{pH}$ and $\mathrm{EC}$ values are within the limits to be used as green compost.

Organic matter was found as $37 \%-47 \%$ in the samples collected from studied metro-cities. This indicates that $\mathrm{OM}$ is in subsequent quantity to make compost out of it. The OM can be further improved by adding sewage sludge or garden waste in MSW. He et al. [28], had mentioned that MSWC increase the buffering capacity of soil and also improve water holding capacity of soil. The MC was found between $24 \%-29 \%$ in the sample; this is not enough for decomposition of organic waste but during aerobic composting water and air supply is periodically supplied to fasten the composting.

\subsection{Total Carbon (C), Nitrogen $(\mathrm{N})$ and Phosphorus (P)}

Carbon, Sulphur, Nitrogen and Phosphorus were estimated in the collected compost samples to access their fertility on agricultural use. The average value for total $\mathrm{C}$ was $21.56 \%$, total $\mathrm{N} 0.85 \%$ and total phosphorus was $2.82 \%$ for Ahmedabad city, Bangalore compost was found with total $\mathrm{C}$ as $26.61 \%$, total $\mathrm{N}$ as $1.13 \%$ and total phosphorus as $2.92 \%$, whereas Delhi's compost samples had total C concentration as $19.56 \%$, total N $1.03 \%$ and total phosphorus as $2.52 \%$ (Table 3). These parameters are essential to understand the compost characterisation which is to be effectively used as fertilizer. The ratio of $\mathrm{C} / \mathrm{N}$ was also analysed and found with in the acceptable range $19-25$, as $20-40 \mathrm{C} / \mathrm{N}$ ratio is considered best to be used. Many authors reported that this ratio can be further improved by adding common waste materials as animal waste, bagasse or garden waste etc. The concentration of $\mathrm{N}$ in MSWC has been seen to increase with composting time as $\mathrm{C}$ is utilized by microorganism [30]. Immature compost can cause $\mathrm{N}$ immobilization due to a high compost $\mathrm{C} / \mathrm{N}$ ratio [31]. In this study Ahmedabad and Bangalore has $\mathrm{C} / \mathrm{N}$ ratio as 25.36 and 23.55 respectively, whereas, in Delhi as 19. Zhang et al. [32], had been reported that MSWC effectively supply P to soil with soil $\mathrm{P}$ concentration increasing with increasing application rates. Thus, MSWC from studied sites could enhance macronutrients concentration in the soil.

\subsection{Bulk Concentration of Heavy Metals in Compost}

Table 4 showed the average heavy metal concentration in MSWC samples from three studied Indian cities. The bulk concentration of heavy metals was found highest for Delhi as $\mathrm{Cu} 48.47, \mathrm{Cr} 36.42$, Ni 34.52, $\mathrm{Pb} 21.76$ and $\mathrm{Cd}$ $2.61 \mathrm{mg} / \mathrm{kg}$, followed by Ahmedabad city as $\mathrm{Cu} 36.68$, Cr 21.14, Ni 26.04, Pb 8.18 and $\mathrm{Cd} 3.69$ and the least concentration was reported in Bangalore city. The average of bulk heavy metals concentration of $\mathrm{Cu}, \mathrm{Cr}, \mathrm{Ni}, \mathrm{Pb}$ and $\mathrm{Cd}$ were reported below the Indian standards for compost according to Municipal Solid Waste (Management and Handling) Rules 2000. This shows that this compost can be used as soil fertilizer as its negative impact seems to be less. Heckman et al. [13], and McBride [14], reported that excessive application of compost may lead to the accumulation of heavy metals in soil surface. Hargreaves et al. [33], had reported that though total and extractable soil $\mathrm{Cu}$ concentration increased when soil was amended with MSWC but in most cases concentration remained below toxic levels to impact plant growth. The risks to the environment, human health, crop quality, yield and soil fertility from source-segregated MSW are minimal [34]. Similarly, other author's world-wide had worked on heavy metals in MSWC and found that heavy metals in compost were within the prescribed limits of their countries and values are given in Table 5.

\subsection{Fractionation of Heavy Metals}

The determination of total concentration of heavy metals could not provide useful information about the risk of bioavailability, transport, toxicity and the capacity for remobilization of heavy metals in the environment [18,35-40]. However, the chemical speciation or fractionation of the heavy metal allows the prediction of its bioavailability and is related to its different natures including the bonding strength, either in free ionic form or complexed by organic matter, or incorporated in the mineral fraction of the sample [16].

Fractionation data to know the bioavailability of metals is more important when a municipal solid waste compost to be used as organic fertilizer, as each fraction would provide the leaching probability of studied metals and subsequently its toxicity. Six fractions had been studied for this paper (F1 to F6) (Figure 1). These fractions are Water-soluble fraction (F1), Exchangeable fraction (F2), Carbonate bound fraction (F3), Fe-Mn oxide fraction (F4), Organic bound fraction (F5) are also called mobile fractions and Residual fraction (F6). Fractions F1 to F5 are mobile or leachable fraction and F6 is not a mobile fraction or residual fraction. The water soluble 
Table 5. Showing heavy metals (mg/kg) values in MSWC and in bracket (numbers) their prescribed limits in same countries.

\begin{tabular}{|c|c|c|c|c|c|c|c|c|}
\hline S. No. & Area & pH & $\mathrm{Cu}$ & $\mathrm{Cr}$ & $\mathbf{N i}$ & $\mathbf{P b}$ & Cd & Hg \\
\hline 1 & $\begin{array}{l}\text { Malian (Belgium) } \\
\text { MSWC }\end{array}$ & 8.44 & 10.30 & - & 6.50 & 3.40 & - & 0.03 \\
\hline 2 & $\begin{array}{c}\text { Setubul (Portugal) } \\
\text { MSWC }\end{array}$ & 8.2 & $357(100-150)$ & $56(100-150)$ & $56(50-75)$ & $269(100-150)$ & $4.3(0.7-1.5)$ & \\
\hline 3 & $\begin{array}{l}\text { Biowaste-indoor } \\
\text { and outdoor MSW } \\
\text { (Netherlands) }\end{array}$ & - & $14(<60)$ & $-(<50)$ & $-(<20)$ & $39(<100)$ & $0.24(<1)$ & $-(<0.3)$ \\
\hline 4 & $\begin{array}{l}\text { MSWC Villarrasa } \\
\text { (Spain) }\end{array}$ & 6.9 & $228(450)$ & - & $38.6(120)$ & $157.6(100)$ & - & - \\
\hline 5 & Greece MSW & - & $301.7(500)$ & - & $31.9(200)$ & $630.7(500)$ & - & - \\
\hline 6 & $\begin{array}{l}\text { Small scale industrial } \\
\text { solid waste of Delhi } \\
\text { (India) }\end{array}$ & $2-9(5.5-8.5)$ & $-(300)$ & - $(50)$ & $651.40(50)$ & $262.0(100)$ & $65.39(5)$ & 1.65 \\
\hline
\end{tabular}

${ }^{1}$ Soumaré et al. [8], ${ }^{2}$ Alvarenga et al. [41], ${ }^{3}$ Veeken et al. [42], ${ }^{4}$ Madrid et al. [43], Lasaridi et al. [44], ${ }^{6}$ Moturi et al. [45].

fraction has loosely bound heavy metals and this is easily available fraction and can enter in life-cycle or food web of plants and animals. Higher concentration of heavy metals in mobile fractions could cause more hazards to the environment.

Copper-The non-residual fraction had $9 \%$ of copper in Ahmedabad city, 6\% in Bangalore city and 16\% in Delhi. The major fraction of $\mathrm{Cu}$ was reported in residual fraction (Figure 1). This has got good agreement with the study done by Moturi et al. [45], in Delhi. They found approximately $5 \%-10 \%$ of $\mathrm{Cu}$ fraction in nonresidual fraction of small-scale industrial solid waste and said that $\mathrm{Cu}$ source in Delhi could be untreated solid waste from small-scale industrial areas generally disposed with MSW in landfill areas. Higher the percentage of heavy metals in non-residual fraction, higher the chances of ground water contamination if MSWC is used for agriculture purpose.

Chromium - $\mathrm{Cr}$ was found in higher percentage in residual fraction ( $87 \%$ for Ahmedabad city, 93\% for Bangalore and $82 \%$ for Delhi). This shows that $\mathrm{Cr}$ fraction was higher in residual or non-leachable fraction of these cities (Figure 1). Therefore, leaching threat from $\mathrm{Cr}$ metal in municipal solid waste compost samples is low.

Nickel-Ni was reported as $9 \%$ and $91 \%, 4 \%$ and $96 \%$ and $9 \%$ and $91 \%$ in non-residual and residual fraction for Ahmedabad, Bangalore and Delhi respectively. Nickel was also found higher in residual fraction of MSWC samples so the chances of leaching from it low.

Lead-This metal was reported as 7\%, 5\% and $12 \%$ respectively in mobile fractions or non-residual fraction of Ahmedabad, Bangalore and Delhi, MSWC samples. Delhi has higher $\mathrm{Pb}$ fraction in MSWC samples then the other cities the reason could be the presence of leachate from un-segregated lead battery in the collected sample. Similar finding was reported by Moturi et al. [45].

Cadmium - Cadmium is one of the toxic metals, toxic- ity of cadmium is well reported by many authors. Higher percentage of $\mathrm{Cd}$ was reported in residual fraction $(93 \%$ in Ahmedabad city, 93\% in Bangalore and 90\% in Delhi). As the leachable or non-residual fraction has only $7 \%$ $10 \%$ of $\mathrm{Cd}$, therefore the contamination chances from $\mathrm{Cd}$ metals would be low. Soumaré et al. [8] also found that Malian and Belgian solid waste compost samples had higher $\mathrm{Cd}$ in residual fraction.

Delhi had higher concentration of total metals in the MSWC subsequently, metals were found high in leachable fractions too [46].

All the metals studied for fractionation studies had highest fraction in residual fractions and this fraction makes little contribution to the heavy metal availability $[8,47]$. Thus, the MSW compost from studied sites is suitable to be used in agricultural purposes. Deportes et al. [48] had reported that availability of metals are less in mature compost as it has more humic acid, thus binds more metals and decrease availability of metals. Similarly, Hargreaves et al. [33] had recommended that a good quality MSWC fully decomposed mature compost, low in metal and salt contents. Therefore, mature MSW compost should be used as mature.

\section{Conclusion}

This study indicates that compost characteristics from studied metropolitan cities of India were found suitable to be used as green compost. As the MSWC studied had $\mathrm{C} / \mathrm{N}$ ratio around 19 - 25 (recommended range 20 - 40) and metal concentration were observed well within acceptable range of the Municipal Solid Waste (Management and Handling) Rules, 2000 of India and with insignificant leachable fraction of heavy metals. The MSWC from Delhi was found with slightly higher concentration of metals then other cities, which could be easily controlled by proper segregation of metallic components 
from MSW. There is need for periodic monitoring of heavy metals in MSWC so that quality could be insured and contamination could be prevented. The quality of compost could be further improved by adding cowdung, bagasse, garden waste etc. The utilisation of MSWC would not only help in recycling of MSW but also increase the fertility of soil and decrease the volume of waste. Also, there is a need to make compost popular among the farmers for its sustainable utilisation.

\section{Acknowledgements}

Authors are thankful to University Grant Commission (UGC) and Department of Science and Technology (DST), Government of India, for providing support to carry out this research work.

\section{REFERENCES}

[1] CPCB, Central Pollution Control Board, "Management of Municipal Solid Wastes," Central Pollution Control Board (CPCB), Government of India, New Delhi, 2002.

[2] M. P. Raut, S. P. M. P. William, J. K. Bhattacharyya, T. Chakrabarti and S. Devotta, "Microbial Dynamics and Enzyme Activities during Rapid Composting of Municipal Solid Waste-A Compost Maturity Analysis Perspective," Bioresource Technology, Vol. 99, No. 14, 2008, pp. 6512-6519. doi:10.1016/j.biortech.2007.11.030

[3] CPCB, "Status of Solid Waste Generation, Collection, Treatment and Disposal in Metrocities, Series: CUPS/ 46/1999-2000," Central Pollution Control Board (CPCB), Government of India, New Delhi, 2000.

[4] A. K. Jha, C. Sharma, N. Singh, R. Ramesh, R. Purvaja and P. K. Gupta, "Greenhouse Gas Emissions from Municipal Solid Waste Management in Indian Mega-Cities: A Case Study of Chennai Landfill Sites," Chemosphere, Vol. 71, No. 4, 2008, pp. 750-758.

doi:10.1016/i.chemosphere.2007.10.024

[5] S. Singhal and S. Pandey, "Solid Waste Management India, Status and Future Direction," TERI Information Monitoring on Environment Science, Vol. 6, No. 1, 2001, pp. 1-4.

[6] I. K. Adewumi, M. O. Ogedengbe, I. J. A. Adepetu and I. P. O. Aina, "Aerobic Composting of Municipal Solid Wastes and Poultry Manure," Journal of Applied Sciences Research, Vol. 1, No. 3, 2005, pp. 292-297.

[7] S. M. Aggelides and P. A. Londra, "Effects of Compost Produced from Town Wastes and Sewage Slugde on the Physical Properties of a Loamy and a Clay Soil," Bioresource Technology, Vol. 71, No. 3, 2000, pp. 253-259. doi:10.1016/S0960-8524(99)00074-7

[8] M. Soumaré, A. Demeyer, F. M. G. Tack and M. G. Verloo, "Chemical Characteristics of Malian and Belgian Solid Waste Composts," Bioresource Technology, Vol. 81, No. 2, 2002, pp. 91-101. doi:10.1016/S0960-8524(01)00125-0
[9] N. B. Mazumdar, "Composting Municipal Solid Waste: The Indian scenario," International Journal of Environment Technology and Management, Vol. 7, No. 3-4, 2007, pp. 326-350.

[10] USEPA, "Wastes-Resource Conservation-Common Wastes and Materials-Organic Materials," 2012.

http://www.epa.gov/osw/conserve/materials/organics/inde x.htm

[11] A. Begum, "Cultivation of Tomato Plants (Lycopersicon Esculentum) Using Municipal Solid Waste Compost," Environmental News, Vol. 16, No. 2, 2010, pp. 5-7.

[12] S. Bose, S. Chandrayan, V. Rai, A. K. Bhattacharyya and Al. Ramanathan, "Translocation of Metals in Pea Plants Grown on Various Amendment of Electroplating Industrial Sludge," Bioresource Technology, Vol. 99, No. 10, 2008, pp. 4467-4475. doi:10.1016/j.biortech.2007.08.020

[13] J. R. Heckman, J. S. Angle and R. L. Chaney, "Residual Effects of Sewage Sludge on Soybean: I. Accumulation of Heavy Metals," Environment Quality, Vol. 16, No. 2, 1987, pp. 113-117. doi:10.2134/jeq1987.00472425001600020004x

[14] M. B. McBride, "Toxic Metal Accumulation from Agricultural Use of Sludge: Are USEPA Regulations Protective," Journal of Environment Quality, Vol. 24, No. 1, 1995, pp. 5-18. doi:10.2134/jeq1995.00472425002400010002x

[15] S. Dudka and W. P. Miller, "Accumulation of Potentially Toxic Elements in Plants and Their Transfer to Human Food Chain," Journal of Environment Science Health, Vol. 34, No. 4, 1999, pp. 681-708.

[16] S. Amir, M. Hafidi, G. Merlina and J. C. Revel, "Sequential Extraction of Heavy Metals during Composting of Sewage Sludge," Chemosphere, Vol. 59, No. 6, 2005, pp. 801-810. doi:10.1016/j.chemosphere.2004.11.016

[17] A. Tessier and P. G. C. Campbell, "Partitioning of Trace Metals in Sediments," In: J. R. Kramer and H. E. Allen, Eds., Metal Speciation: Theory, Analysis and Application, Lewis Publications, Chelsea, 1988, pp. 183-199.

[18] L. Q. Ma and G. N. Rao, "Chemical Fractionation of Cadmium, Copper, Nickel and Zinc in Contaminated Soils," Journal of Environment Quality, Vol. 26, No. 1, 1997, pp. 259-264. doi:10.2134/jeq1997.00472425002600010036x

[19] J. R. Okalebo, K. W. Gathua and P. L. Woomer, "Laboratory Methods of Soil and Plant Analysis: A Working Manual," Marvel EPZ (Kenya) LDT, Nairobi, 1993.

[20] D. H. Loring and R. T. T. Rantala, "Manual for the Geochemical Analyses of Marine Sediments and Suspended Particulate Matter," Earth Science Review, Vol. 32, No. 4, 1992, pp. 235-283. doi:10.1016/0012-8252(92)90001-A

[21] A. Tessier, P. G. C. Campbell and M. Bisson, "Sequential Extraction Procedure for the Speciation of Particulate Trace Metals," Analytical Chemistry, Vol. 51, 1979, pp. 844-851. doi:10.1021/ac50043a017

[22] Y. M. Luo and P. Christie, "Bioavailability of Copper and Zinc in Soils Treated with Alkaline Stabilized Sewage Sludges," Journal of Environment Quality, Vol. 27, No. 2, 
1998, pp. 335-342. doi:10.2134/jeq1998.00472425002700020013x

[23] V. D. Zheljazkov and P. R. Warman, "Application of High $\mathrm{Cu}$ Compost to Swiss Chard and Basil," The Science of Total Environment, Vol. 302, No 1-3, 2003, pp. 13-26. doi:10.1016/S0048-9697(02)00390-X

[24] J. Ciba, M. Zolotajkin, J. Kluczka, K. Loska and J. Cebula, "Comparison of Methods for Leaching Heavy Met als from Composts," Waste Management, Vol. 23, No. 10, 2003, pp. 897-905. doi:10.1016/S0956-053X(03)00128-4

[25] C. Wang, X. C. Li, H. T. Ma, J. Qian and J. B. Zhai, "Distribution of Extractable Fractions of Heavy Metals in Sludge during the Wastewater Treatment Process," Journal of Hazardous Materials, Vol. 137, No. 3, 2006, pp. 1277-1283. doi:10.1016/j.jhazmat.2006.04.026

[26] M. Mkhabela and P. R. Warman, "The Influence of Municipal Solid Waste Compost on Yield, Soil Phosphorus Availability and Uptake by Two Vegetable Crops, Grown in Pugwash Sandy Loam in Nova Scotia," Agriculture, Ecosystem, Environment, Vol. 106, No. 1, 2005, pp. 5767. doi:10.1016/i.agee.2004.07.014

[27] N. Brady and R. Weil, "The Nature and Properties of Soils," 12th Edition, Prentice, Upper Saddle River, 1996.

[28] X. He, T. Logan and S. Traina, "Physical and Chemical Characteristics of Selected US Municipal Solid Waste Composts," Environmental Quality, Vol. 24, No. 3, 1995, pp. 543-552. doi:10.2134/jeq1995.00472425002400030022x

[29] T. Manios, "The Composting Potential of Different Organic Solid Wastes: Experience from the Island of Crete," Environment International, Vol. 29, No. 8, 2004, pp. 1079-1089. doi:10.1016/S0160-4120(03)00119-3

[30] R. Wolkowski, "Nitrogen Management Consideration for Land Spreading Municipal Solid Waste Compost," Environmental Quality, Vol. 32, No. 5, 2003, pp. 1844-1850. doi:10.2134/jeq2003.1844

[31] A. Garcia-Gomez, M. Bernal and A. Roig, "Carbon Mineralization and Plant Growth in Soil Amended with Compost Samples at Different Degrees of Maturity," Waste Management Research, Vol. 21, No. 2, 2003, pp. 161171. doi: $10.1177 / 0734242 X 0302100210$

[32] M. Zhang, D. Heaney, B. Henriquez, E. Solberg and E. Bittner, "A Four Year Study on Influence of Biosolids/MSW Cocompost Application in Less Productive Soils in Alberta Nutrients Dynamics," Compost Science Utilization, Vol. 14, No. 1, 2006, pp. 68-80.

[33] J. C. Hargreaves, M. S. Adi and P. R. Warman, "A Review of the Use of Composted Municipal Solid Waste in Agriculture," Agriculture, Ecosystems and Environment, Vol. 123, No. 1-3, 2008, pp. 1-14. doi:10.1016/j.agee.2007.07.004

[34] T. Richard and P.Woodbury, "The Impact of Separation on Heavy Metals Contaminants in Municipal Solid Waste Composts," Biomass Bioenergy, Vol. 3, No. 3-4, 1992, pp. 195-211. doi:10.1016/0961-9534(92)90026-M

[35] G. J. Chakrapani and V. Subramanian, "Fractionation of Heavy Metals and Phosphorus in Suspended Sediments of the Yamuna River, India," Environment Monitoring and Assessment, Vol. 43, No. 11, 1996, pp. 7-124.

[36] M. J. Belcunze-Segarra, J. R. Bacon, R. Prego and M. J. Wilson, "Chemical Forms of Heavy Metals in Surface Sediments of the San Simon Inlet, Ria de Vigo," Galicia. Environment Science Health, Vol. 32, No. 5, 1997, pp. 1271-1297.

[37] S. M. Charlesworth and J. A. Lees, "Particulate-Associated Heavy Metals in the Urban Environment: Their Transport from Source to Deposit, Coventry, UK," Chemosphere, Vol. 39, No. 5, 1999, pp. 833-848. doi:10.1016/S0045-6535(99)00017-X

[38] A. Fernández, B. Pérez Cid, E. Fernández Gómez and E. Falqué López, "Comparison between Sequential Extraction Procedures and Single Extractions for Metal Portioning in Sewage Sludge Samples," Analyst, Vol. 125, No. 7, 2000, pp. 1353-1357. doi:10.1039/b001983f

[39] T. Kunito, K. Saeki, S. Goto, H. Hayashi, H. Oyaizu and S. Matsumoto, "Copper and Zinc Fractions Affecting Microorganisms in Long-Term Sludge-Amended Soils," Bioresource Technology, Vol. 79, No. 2, 2001, pp. 135146. doi:10.1016/S0960-8524(01)00047-5

[40] M. C. Z. Moturi, M. Rawat and V. Subramanian, "Distribution and Partitioning of Phosphorus in Solid Waste and Sediments from Drainage Canals in the Industrial Belt of Delhi, India," Chemosphere, Vol. 60, No. 2, 2005, pp. 237-244. doi:10.1016/j.chemosphere.2004.11.032

[41] P. Alvarenga, P. Palma, A. P. Gonçalves, R. M. Fernandes, A. C. Cunha-Queda, E. Duarte and G. Vallini, "Evaluation of Chemical and Ecotoxicological Characteristics of Biodegradable Organic Residues for Application to Agricultural Land," Environment International, Vol. 33, No. 4, 2007, pp. 505-513. doi:10.1016/j.envint.2006.11.006

[42] A. Veeken and B. Hamelers, "Sources of $\mathrm{Cd}, \mathrm{Cu}, \mathrm{Pb}$ and $\mathrm{Zn}$ in Biowaste," The Science of the Total Environment, Vol. 300, No. 1-3, 2002, pp. 87-98. doi:10.1016/S0048-9697(01)01103-2

[43] F. Madrid, R. López and F. Cabrera, "Metal Accumulation in Soil after Application of Municipal Solid Waste Municipal Solid Waste under Intensive Farming Conditions," Agriculture, Ecosystems \& Environment, Vol. 199, No. 3-4, 2007, pp. 249-256. doi:10.1016/i.agee.2006.07.006

[44] K. Lasaridi, I. Protopapa, M. Kotsou and G. Pilidis, "Quality Assessment of Composts in the Greek Market: The Need for Standards and Quality Assurance," Journal of Environmental Management, Vol. 80, No. 1, 2006, pp. 58-65. doi:10.1016/j.jenvman.2005.08.011

[45] M. C. Z. Moturi, M. Rawat and V. Subramanian, "Distribution and Sequential Extraction of Heavy Metals in Solid Waste from the Industrial Belt of Delhi, India," Environment Monitoring and Assessment, Vol. 95, No. 1-3, 2004, pp. 185-199. doi:10.1016/j.envint.2008.06.009

[46] R. S. Smith, "A Critical Review of the Bioavailability and Impacts of Heavy Metals in Municipal Solid Waste Composts Compared to Sewage Sludge," Environment International, Vol. 35, No. 1, 2009, pp. 142-156. 

Study for Its Sustainable Utilisation

[47] L. Yangsheng, M. Lanlan, L. Yaqiong and Z. Liting, "Evolution of Heavy Metal Speciation during the Aerobic Composting Process of Sewage Sludge," Chemosphere, Vol. 67, No. 5, 2007, pp. 1025-1032.

doi:10.1016/j.chemosphere.2006.10.056
[48] L. Deportes, J. Benoit-Guyod and D. Zmirrou, "Hazard to Man and the Environment Posed by the Use of Urban Waste Compost: A Review," The Science of Total Environment, Vol. 172, No. 2-3, 1995, pp. 197-222. doi:10.1016/0048-9697(95)04808-1 